\title{
Scoring Local Economic Development Goals in South Africa: Why Local Government is Failing to Score
}

Costa Hofisi

North-West University

Roland Mbeba

University of Fort Hare

\section{Andrew Maredza}

North-West University

Ireen Choga

Doi:10.5901/mjss.2013.v4n13p591

North-West University

\begin{abstract}
Local Economic Development entered the development lexicon in South Africa in the 1990s and from that time it has become not just an "isolated local development initiative" but an obligation for all local authorities according to a plethora of government policies and the South African Constitution of 1996. While this paper explicates the Local Economic Development episteme in South Africa, it also seeks to explore reasons for the demise of local economic development in South Africa. The paper is exploratory and descriptive in design and relied on extensive literature review. It argues that LED in South Africa suffers from both conceptual imprecision and theoretical underdevelopment. The assumption of a local economy underpinning LED is also questioned in an era of globalisation. Moreover, other challenges confronting the success of LED in the country highlighted entail lack of local government capacity for implementation, funding for LED, lack of effective planning methodologies and failure to manage participation at the local level.
\end{abstract}

Keywords: Local Economic Development, Local Government, Capacity.

\section{Introduction}

While Local economic development has been a buzzword in South Africa, its failure has been highlighted in extensive literature (Hindson, 2003; Nel, 2001; Rogerson 2010; Helmsing 2001; Nel et al, 2002; Tomilson, 2003; Meyer-Stamer, 2003; Aghón et al. 2001). However, the 'invention' of LED as a major policy focus over recent years is neither unique to South Africa nor by coincidence. (RSA 1996; Nel \& Rogerson, 2007). The emergence of Local Economic Development is explained by various government policies and the requirements of the 1996 National Constitution which highlights the obligation for Local Government to spearhead economic development at a local level. Consequently, this obligation is inherent in the LED policy framework and other related local government pieces of legislation, premised on the South African Constitution of 1996. Sections 152 (c) and 153 (a) of the Constitution, 1996 outline that local government should "promote social and economic development" and must "structure and manage its administration, and budgeting and planning processes to give priority to the basic needs of the community, and to promote the social and economic development of the community" (Patterson. 2008).

Moreover, the South African constitution establishes "developmental local government" which implies that the LED agenda in the context of South Africa, unlike in other countries is neither voluntary nor just a local government initiative but a constitutional requirement. The IDP process, encompassing LED is a fundamental vehicle for driving the development agenda of local government. In Integrated Development Planning LED "more often than not relates to infrastructure and buildings, not to other typical LED interventions like business networking or business development service programmes" (Meyer-Stamer, 2006). 


\section{Local Economic Development: A Conceptual and Theoretical Framework}

The efficacy of LED is compounded by various conceptualisations of what LED actually is. This can be partly attributed to the different understanding of the two approaches that embody the concept of LED, namely the market-led/pro-growth LED and 'pro-poor' LED or 'non-developmental' and 'developmental' LED). The operationalization of these two approaches for effective implementation of LED has proved to be a difficulty to local government officials (Abrahams, 2003).

Nel and Rogerson define LED as a "process of creating wealth through the organised mobilisation of human, physical, financial, capital and natural resources in a locality" Moreover, according to Meyer-Stamer (2006), LED in South Africa is being approached from three different angles, which are the poverty alleviation, urban planning and the business-oriented angle. The "poverty alleviation angle" focuses on small projects, which struggled due to poor support structures and poor basic design, and poor structures of governance. Most of strategies of LED in the 2008 Integrated Development Plans (IDPs) are almost entirely project focused' (Van der Heijden, 2008:12). The Good Governance Learning Network (GGLN) maintains that the "successes of project-focused LED were limited and where interventions did work, they tended to be linked with tourism" (Rogerson, 2011).

On the other hand, there is the urban planning angle, which according to Meyer-Stamer (2006); includes infrastructure development and, most of all, the IDP process, this approach to LED is planning-driven, meaning that there is a long period between the conceptualisation of a project and the observation of its impact on the ground. This is so as there is need to carefully plan for future economic events and projects. However, the longer it takes LED initiatives to produce results the more it drives away potential investors in the area. For instance, businesses usually seek to see immediate impact of their projects due to the uncertainty of the dynamic economic environment. Caution must be ensured as planning and LED do not have the same meaning, although there is a close relationship between the two. This kind of planning is reciprocal to the shift in development planning in South Africa since 1994, where there has been a radical transformation in the nature and organisation of developmental planning. One of the most significant shifts relates to the rise of LED planning, an integral component of 'place-reshaping', and of 're-engineering local government' in South Africa (Grant \& Dollery, 2010, Thornhill, 2008, cited in Rogerson, 2010).

The business-oriented angle in South Africa is rarely followed as the businesses are of the belief that LED in the doctrine is nothing short of all talk and no action, thus the business sector is thus only occasionally involved in LED; often withdraw their contributions (Meyer-Stamer, 2006). The business-oriented angle invariably would focus on increasing competitiveness of a locality. The LED approach that focused on competitiveness evolved and was adopted in South Africa's cities.

In major cities of South Africa such as Johannesburg, Durban, Cape Town, Pretoria and Ekurhuleni, the "mainstream LED practice has been dominated by market-led approaches that have been increasingly geared towards achieving competitiveness and sustainable high economic growth rates" (Rogerson, 2011). From this perspective, it is however evident that, less effort was being directed towards the market-critical LED approach, which not only facilitates the functionality of the local markets and their competitiveness, but also conjoin market development as well as socioeconomic development and infrastructural development (Rogerson, 2011). Thus, there has been a paradigm shift in LED South Africa.

The efficacy of LED in South Africa has been widely criticised, LED policies and focus have been criticised for their failure to address inequality and poverty. Hindson (2003) and Nel (2001), argue that the disappointing LED results in South Africa can be attributable to resource and capacity constraints compounded by limited experience of local government in terms of promoting economic development. On the other hand, Rogerson (2003) and Helmsing (2001) argue that the marginalisation of non-local government actors in LED in South Africa fails to adhere to the international best practice in partnership formation and collaboration which is a critical ingredient for the effectiveness of the implementation of LED strategies. The exclusion of the private sector in development, pursuit of individual interests and politicisation of development efforts have also been identified as impediments to LED (Nel et al, 2002, Tomilson, 2003). Rogerson (2000) also stresses that in South Africa's LED policy, "there appears to be an emphasis on a strong pro poor focus in rhetoric even though it is not always practiced".

\section{3. "Strategic Challenges" Confronting Local Economic Development}

Rogerson (2010) identifies what he calls "strategic challenges" which confront LED implementation in South Africa, some of which are the following: lack of capacity at local government level; lack of funding for LED; ineffective LED 
methodologies for planning; poor coordination of networks. Moreover, we also argue that the conceptualisation of LED is blurred while theoretically, LED is underdeveloped and this further erodes the capacity of municipalities to successfully conceptualise and implement strategies for LED. Moreover, the assumption of a local economy underpinning LED is problematic in an era of globalisation. Given the integration of national economies in the global economy compounded by the asymmetries of global economic power, to what extent is LED feasible?

\subsection{Poor LED networks and unsustainable knowledge platforms}

While the building of sustainable "sound and concrete networks" is sine qua non for effectiveness and efficiency of LED implementation to be realised it is worrying that this has remained a challenge in the South African context. What makes the situation worse is that South Africa has three spheres of government, namely national, provincial and local and it has been observed widely that vertical and horizontal coordination of programmes in the three spheres is a serious challenge, let alone the coordination of LED networks. Moreover, what compounds the situation is the lack of capacity in government for strategic management. It is therefore important that the South African government takes issues of capacity development seriously for effective LED implementation to be realised.

\subsection{Local Government Capacity}

One of the major shortcomings of LED implementation is the lack of capacity within local government's human capital. Local government in South Africa had service delivery as its traditional focus, implying that there is a dearth of LED professionals in the country especially in smaller municipalities. The expertise and qualifications of key personnel holding Strategic LED portfolios has been questioned, this factor inhibits "the incumbents' ability to negotiate and strategise with the often intimidating private sector, who are big stumbling blocks to the effective implementation of LED initiatives" (Lawrence \& Hadingham 2008:44, as cited in Rogerson, 2010). This lack of capacity in the municipalities has resulted in overreliance on consultancies which does not only drain financial resources of the municipality but also leads to LED strategies which do not address the reality on the ground. This is confirmed by Van der Heijden (2008) who observes that "the outcome will be a cumulative trend towards the production of low-quality LED plans marked by a project focus, unrealistic targets, an inability to identify the drivers of local development and poor implementation". Against this background of LED Nel (2001) argues that Local government officials need training and exposure to the LED concept. Moreover, it is important that capacity building efforts are directed towards poorer municipalities which are currently limping when it comes to effective implementation of LED programmes (Rogerson, 2010).

\subsection{Lack of Quality local data}

Good local level data for planning purposes of which its availability has deteriorated since 1994 is quite essential for local authorities and LED officials to make informed decisions in the implementation of LED initiatives. The improvement of the quality of data for planning at a local level is a major challenge for LED stakeholders (Sibisi, 2009 as cited in Rogerson, 2010). Alternative methods of acquiring latest local data to compensate for the inadequate available data, would be to rely on purchasing local or regional data sets available from private sector enterprises such as Global Insight or Quantec another suggestion is "to explore the development of local economic models that can be based upon municipal expenditure" (Rogerson, 2010). This is crucial as one of the major challenges faced by LED in South Africa is "to improve the quality of local data to improve understanding of local economies, identify local competitiveness and assist LED decision-making" (Rogerson, 2008). Thus, there is the critical need for "much more effective analytical tools, and to focus on the real economic challenges such as accurate economic data and value chain analysis" (Van der Heijden, 2008:16 as cited in Rogerson). Good local level data which includes an economic profile of the local area updated containing meaningful local-scale economic data is crucial for effective LED planning (Van der Heijden, 2008). For instance, the lack of data for major sectors such as tourism, creative industries, or craft, of which no "spatially disaggregated basis exists which might inform the identification of competitive advantage and enhance LED planning for these critical sectors" Rogerson (2010). It is imperative that, a collective effort, which involves all the significant stakeholders, more so across all levels of government, should be directed towards gathering improved data. 


\subsection{LED Funding and the Second Economy}

The contested concept of the 'second economy' has been deemed to be misguided by various authors, with Devey et al (2006); Sibisi, (2009); Rogerson, (2010) asserting that the idea of evolving "second economy strategies" which are 'separate' from "first economy strategies" is imprudent. Moreover, the second economy concept is a challenge confronting LED officials who are still "grappling with the challenge of understanding and developing appropriate strategies to address the informal economy and associated livelihood strategies that often buck against national planning frameworks and paradigms" (DBSA, 2008:3 cited in Rogerson 2010). Critical importance is attached towards the need for the development of a support strategy for the second economy, which will enable the local communities to engage more directly with the LED agenda and with LED processes to access and influence LED debates. The extension of social grants, smallholder development, cooperatives, the Expanded Public Works Programme are among several "interventions to support the second economy and initiatives to establish value chains in poorer areas as a means of keeping money in circulation in those areas before moving back to the first economy" (Philip \& Hassen, 2008, as cited in Rogerson, 2010). Most importantly, LED policy-makers and practitioners in South Africa must ensure that the issues of the second economy do not fall off the policy agenda with a re-balancing of LED towards a central focus on building local competitiveness.

LED initiatives require a great deal of funds, which will enable local authorities to drive the LED process independently. However, it has been argued by LED officials that LED constitutes an unfunded mandate on the part of local government due to several factors. Access and the availability of funds has been a major stumbling block for especially local authorities 'who struggle for funds due to limited internal capacity constraints, which generally affect their credit rating and weak revenue base, and bar them from accessing standard concessional loan instruments' (DBSA, 2008:3). It is worrying that the funds available at local and national level are insecure, and to alleviate the situation, Patterson (2008), maintains that "generally LED has few secure funding sources and often relies on charitable donations and public grants". This means that local and international non-governmental organisations or donors are significant actors for many local authorities in terms of either accessing or making available direct funding for local development initiatives (Rogerson, 2010).

\section{Conclusion}

While local economic development has been hailed as a vehicle for championing economic development by government there is scant evidence pointing to its success where it has been pursued. Moreover, key pertinent questions bedevil local economic development such as; what is local economic development? What is local economic development theory? Do municipalities in South Africa have capacity for the effective implementation of LED? How is participation by local stakeholders envisaged in LED supposed to be managed? What is participation? Who owns the participatory process? Is there adequate funding for the LED agenda? What is this "local economy" which must be developed? Although, LED is a constitutional requirement on the part of local Government, LED in South Africa suffers from both conceptual imprecision and theoretical underdevelopment. The assumption of a local economy underpinning LED is problematic in an era of globalisation. Given the integration of national economies in the global economy compounded by the asymmetries of global economic power, to what extent is LED feasible? Moreover, other challenges confronting the success of LED in the country highlighted entail lack of local government capacity for implementation, funding for LED, lack of effective planning methodologies. It is against this background that we argue that a thorough conceptualisation of LED is necessary while Local Government capacity for LED implementation must be developed.

\section{References}

Abrahams, D, 2003. Local Economic Development in South Africa; a Useful tool for Sustainable Development. Urban Forum, 14: 2.

Bond, P. 1998. Local Economic Development And The Municipal Services Crisis in Post-Apartheid South Africa .The Case of Stutterheim. Urban Forum 9: 2.

Bond, P. 2003. Debates in Local Economic Development Policy and Practice. Urban Forum, 14:2.

Carroll, M. C., Blair, J. P. 2010. Local economic development and the academy, Applied Geography (2010), doi:10.1016/j.apgeog .2010.11.013

Development Bank of Southern Africa, 2008. Local Economic Development Fund: Concept and Modus Operandi. DBSA, Halfway House.

Gibb, M. \& Nel, E. 2007. Small Town Redevelopment: The Benefits and Costs of Local Economic Development in Alicedale. Urban 
Forum, 18:69

Hadingham, T, 2008. The South African LED network: From spectator to participant. @local.glob, 5: 54.

Helmsing, A. J. H. (2001): Partnerships, Meso-institutions and Learning. New local and Regional Economic Development Initiatives in Latin America. The Hague: Institute of Social Studies (mimeo).

Hill.T, Nel.E \&Trotter.D,2006. Small-scale, nature-based tourism as a pro-poor development intervention: Two examples in KwazuluNatal, South Africa. Discipline of Geography, School of Environmental Sciences, University of KwaZulu-Natal, Pietermaritzburg, South Africa.eprints.ru.ac.za

Hindson, D. 2003. Connecting economic growth with poverty alleviation: South Africa's LED challenge, Hologram, 1, 1, 2-7.

Hindson, D; Hindson, V. \& Preddie, M. 2003. Rapid Review of LED in the Eastern Cape. Department of the Eastern Cape, Premiers' Office.

Helmsing, A. J. H. 2003. Local Economic Development: New Generators of Actors, Policies and Instruments for Africa" in Public Administration and Development, no 23, pp.67-76.

Lawrence, F \& Hadingham, T, 2008. Decentralisation and the challenge of institutionalising local economic development: Some practical insights from the South African experience, @local. glob 5. Delnet Programme ILO: Turin.

Meyer-Stamer, J. 2006. The Hexagon of Local Economic Development and LED in South Africa. Duisburg: Mesopartner.

Mbuli. B. N. 2008. Poverty Reduction Strategies in South Africa. Thesis submitted in fulfilment of a Master of Commerce at the University of South Africa.

Molefane, M. 2006. An analysis of municipal economic development capacity: Case Study of Ekurhuleni Metropolitan Municipality. Unpublished Masters Research, University of the Witwatersrand. Johannesburg.

Nel. E \& Rogerson. C. M, 2007. Evolving Local Economic Development Policy and Practice in South Africa with Special Reference to Smaller Urban Centres. Urban Forum 18:1

Nel.E.L \& Binns.T, 2002. Place Marketing, Tourism Promotion, and Community based Local Economic Development in Post-Apartheid South Africa: The Case of Still Bay --The "Bay of Sleeping Beauty". Urban Affairs Review, 38: 184.

Nel, E.L. and Binns, T. 2001. Initiating 'developmental local government' in South Africa: evolving local economic development policy, Regional Studies, 35 (4), 355-362.

Nel, E. (2001). Local economic development: A review and assessment of its current status in South Africa. Urban Studies, 38: 10031024

Pieterse, E., (ed.) 1998. A framework to link LED to anti-poverty strategies, in Isandla Institute, Linking Local Economic Development to Poverty Alleviation, 37-54, Department of Constitutional Development, Pretoria.

Rogerson, C.M. 2011. Tracking Local Economic Development Policy and Practice in South Africa, 1994-2009. Urban Forum DOI 10.1007/s12132-011-9113-1.

Rogerson, C.M. 2010. Local economic development in South Africa: Strategic challenges. Development Southern Africa Vol. 27, No. 4, October 2010.

Rogerson, C.M. 2003. Towards Pro-Poor Local Economic Development: The Case for Sectoral Targeting in South Africa. Urban Forum, 14: 1.

Rogerson .C.M. 2000. Local Economic Development in an Era of Globalization: The Case of South African Cities. Royal Dutch Geographical Society, KNAG.

RSA, 1998a: The White Paper of Local Government. Department of Constitutional Development: Pretoria.

RSA, 1998c: Local Government Municipal Structures Act, Act No. 117 of 1998.

RSA, 2000. Municipal Systems Act, N0; 32 of 2000. Department of Local Government.

Sibisi, S. 2009. Brushing against the grains of history: Making local economic development work in South Africa. Development Planning Division Working Paper Series No.5, DBSA: Midrand.

Tomlinson. R. 2003. The Local Economic Development mirage in South Africa. Geoforum 34:113-122.

Van der Heijden, T. 2008. Key issues in Local Economic Development in South Africa and a potential role for SALGA. Position paper prepared for the South African Local Government Association, Pretoria 
